\title{
Disposition of the sinus node in left-sided juxtaposition of the atrial appendages
}

\author{
S. YEN HO, JAMES L. MONRO, AND ROBERT H. ANDERSON ${ }^{1}$ \\ From the Department of Paediatrics, Cardiothoracic Institute, Brompton Hospital, London; \\ and Wessex Cardiothoracic Surgical Centre, Southampton
}

SUMMARY In view of the complex cardiac anomalies frequently associated with left-sided juxtaposition of the atrial appendages the disposition of the sinus node has been studied in 6 of these hearts. While the sulcus terminalis still provides a landmark to the position of the node, the nodes were in an anterior position in all 5 hearts with complete juxtaposition, 2 being inferior to the crista terminalis. The node was in a more normal, lateral position in the sixth case with partial juxtaposition.

The disposition of the sinus node originally described by Keith and Flack (1907) has since been well investigated (for example Davies, 1942; Hudson, 1960; Challice, 1966; James et al., 1966; Truex et al., 1967; Lev, 1968; James, 1970; Anderson et al., 1979). As the right atrium and its appendage are common sites for manipulation, placement of sutures, and cannulation in cardiac surgery, it is imperative that the areas bearing the sinuatrial node and its arterial supply be avoided.

To the best of our knowledge the disposition of the sinuatrial node has not yet been ascertained in hearts with juxtaposed atrial appendages. Normally each atrial appendage lies to one side of the great arteries. The term 'juxtaposition of the atrial appendages' was coined by Dixon (1954) to describe the condition whereby both atrial appendages were adjacent to each other and lie to the same side of the great arteries. As juxtaposition is often associated with complex cardiac malformations (Melhuish and Van Praagh, 1968) requiring correction or palliation for continuing life, precise knowledge of the location of the sinus node in the malformation is of paramount importance. For instance, correction of ventriculoarterial discordance, a commonly associated anomaly with juxtaposition (Melhuish and Van Praagh, 1968; Rosenquist et al., 1974; Allwork et al., 1977), by Mustard's repair would involve considerable atrial manipulation. A similar situation would arise if tricuspid atresia, another frequent association (Melhuish and Van Praagh, 1968), was present

${ }^{1}$ R.H.A. is supported by the Joseph Levy Foundation together with the British Heart Foundation.

Received for publication 26 June 1978 and a conduit was attached to the right atrium in attempting correction (Fontan and Baudet, 1971).

For these reasons we have ascertained the disposition of the sinus node in 6 patients with leftsided juxtaposition of the atrial appendages.

\section{Subjects and methods}

Six hearts with both right and left atrial appendages to the left of the great arteries were available for

Table Postmortem diagnoses of 6 specimens with left-sided juxtaposition

\begin{tabular}{|c|c|c|}
\hline $\begin{array}{l}\text { Case } \\
\text { no. }\end{array}$ & $\begin{array}{l}\text { Segmental arrangement } \\
\text { Situs-AV connection- }-A A \\
\text { connection }\end{array}$ & $\begin{array}{l}\text { Associated cardiac } \\
\text { anomalies }\end{array}$ \\
\hline 1 & $\begin{array}{l}\text { Solitus-absent right connec- } \\
\text { tion-discordant (univentri- } \\
\text { cular heart LV type) }\end{array}$ & $\begin{array}{l}\text { Secundum ASD; right } \\
\text { sided OC; persistent } \\
\text { LSVC; coarctation and } \\
\text { tubular hypoplasia }\end{array}$ \\
\hline 2 & $\begin{array}{l}\text { Solitus-concordant-single } \\
\text { aortic trunk }\end{array}$ & $\begin{array}{l}\text { Secundum ASD, straddling } \\
\text { TV; pulmonary atresia; } \\
\text { persistent LSVC }\end{array}$ \\
\hline 3 & Solitus-concordant-discordant & $\begin{array}{l}\text { ASD; VSD (subaortic), } \\
\text { pulmonary stenosis; } \\
\text { PDA, right aortic arch }\end{array}$ \\
\hline 4 & $\begin{array}{l}\text { Solitus-concordant-DORV- } \\
\text { with right-sided aorta }\end{array}$ & ASD, VSD (extensive) \\
\hline 5 & $\begin{array}{l}\text { Solitus-concordant-DORV- } \\
\text { with left-sided aorta }\end{array}$ & $\begin{array}{l}\text { PFO; VSD (posterior) } \\
\text { pulmonary outflow } \\
\text { stenosis }\end{array}$ \\
\hline 6 & Solitus-concordant-discordant & $\begin{array}{l}\text { PFO: VSD (extensive); } \\
\text { tricuspid atresia }\end{array}$ \\
\hline
\end{tabular}

ASD, atrial septal defect; AV, atrioventricular; LV, left ventricular; OC, outlet chamber; PDA, persistent ductus arteriosus; PFO, patent foramen ovale; TV, tricuspid valve; VA, ventriculoarterial; VSD, ventricular septal defect; LSVC, left superior vena cava. 


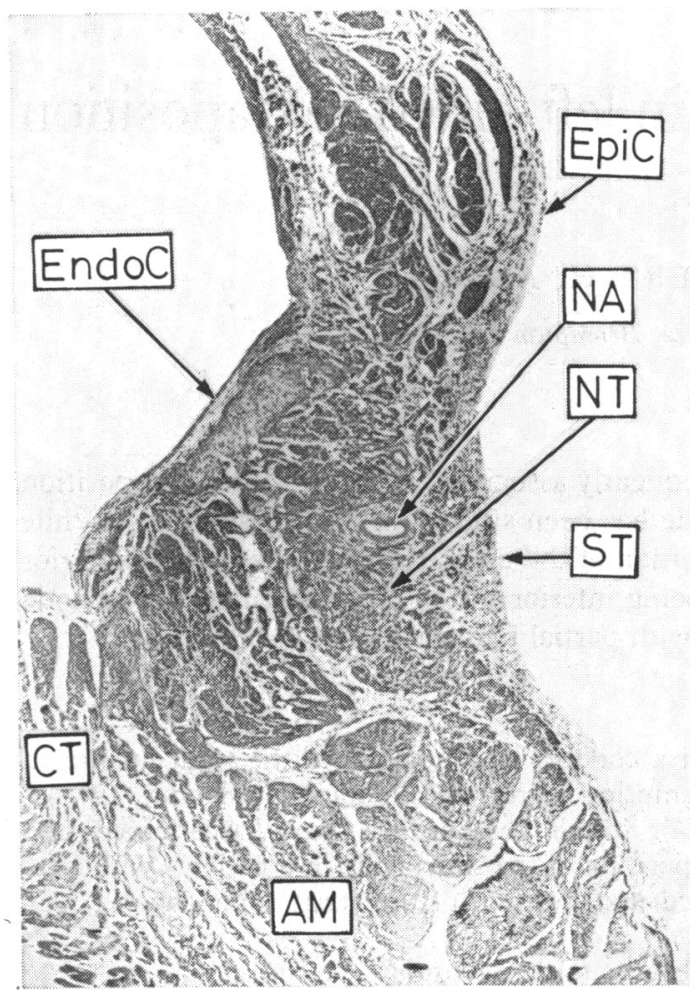

Fig. 1 Photomicrograph of a longitudinal section through the atrio-caval junction of a normal heart. Nodal tissue $(N T)$ is related to a nodal artery $(N A)$. The sinus node is subepicardial and located in the sulcus terminalis $(S T)$. AM, atrial myocardium; $C T$, crista terminalis; EndoC, endocardium; EpiC, epicardium. (Trichrome stain. $\times 46$.)

Fig. 2 The photomicrograph on the left is a section through specimen 1. The sinus node is inferior to the crista terminalis and towards the atrioventricular sulcus. The rectangle marks the area shown on the right photomicrograph. The sinus node is related to a nodal artery. AVS, atrioventricular sulcus; $C T$, crista terminalis; $P A$, pulmonary artery; $R A$, right atrium; $S V C$, superior vena cava; $V$, ventricle; $A M$, atrial myocardium; EndoC, endocardium; EpiC, epicardium; $N A$, nodal artery; $N T$, nodal tissue. (Elastic van Gieson stain. $\times 3.4$ and $\times 23$.)

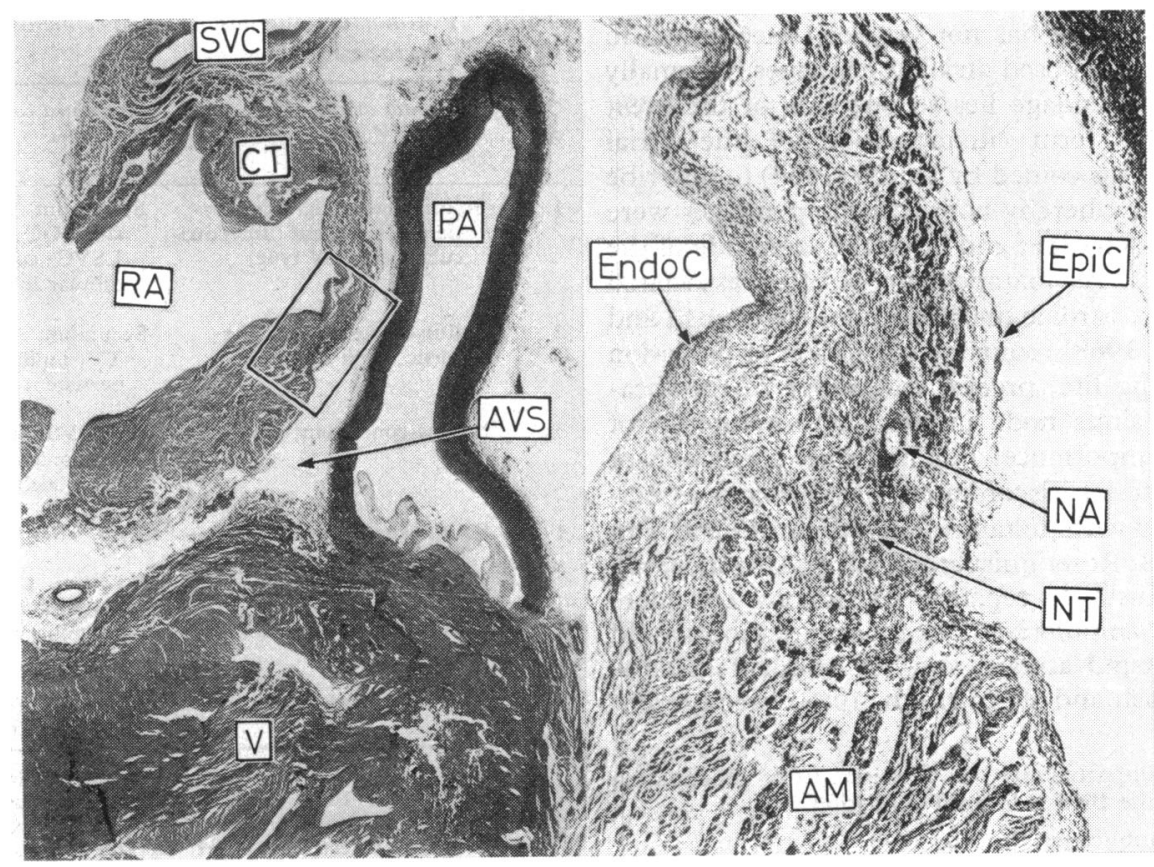


study from the Brompton Hospital collection. One of these had partial juxtaposition in that though a large part of the right atrial appendage was juxtaposed to the left, a small portion remained to the right of the great arteries. Two of the hearts were processed and embedded in paraffin wax in toto. Each block was then serially sectioned in a sagittal plane from right to left at $10 \mu$ thickness. Every 25th section was mounted and stained using Masson's trichrome technique. Additional sections were stained as deemed necessary after initial examination. After locating the sinus node in these 2 hearts, strips of atrial wall expected to bear the sinus node were excised from the third to fifth hearts and prepared as above. The entire right and left atria were removed in a single block from the sixth heart, processed, and sectioned transversely.

\section{Results}

The complex associated malformations in the hearts studied are shown in the Table.

The sinus node was identified in all cases. In terms of histology the structure of the nodes was no different from those of normal hearts which we studied in another investigation (Anderson et al., 1979, Fig. 1). However, the position of the node showed considerable variation, both from the normal and among the hearts studied. The first 2 specimens had persistent left superior venae cavae but no specialised tissue was seen in its vicinity. The sinuatrial node in these 2 cases was seated in the anterior wall of the right atrium in the dip of the atrioventricular sulcus (Fig. 2 and 3). The nodes werenearly spindle-shaped and supplied by a small central artery which was a branch of an anterior atrial artery. There was no evidence of a branch to the sinuatrial junction.

The third and fourth specimens also had spindleshaped sinuatrial nodes but they were located anteriorly at the sinuatrial junction (Fig. 3). The node in the fourth specimen was somewhat dispersed and the matrix was very fibrous. Also, the vicinity of this node was haemorrhagic. The nodal arteries were eccentric in relation to the nodes.

The node in the fifth specimen was on the anterior atrial wall, inferior to the sinuatrial junction (Fig. 3). It was shaped like a flattened spindle and located subepicardially. The matrix was mainly fibrous and some adipose tissue was also seen. The nodal artery was large.

The sixth case, which had partial juxtaposition, had the sinuatrial node in a more 'normal' position. It nestled in the sulcus terminalis between the 'bud' of the right atrium and the superior vena cava and stretched across to the lateral side (Fig. 3). The
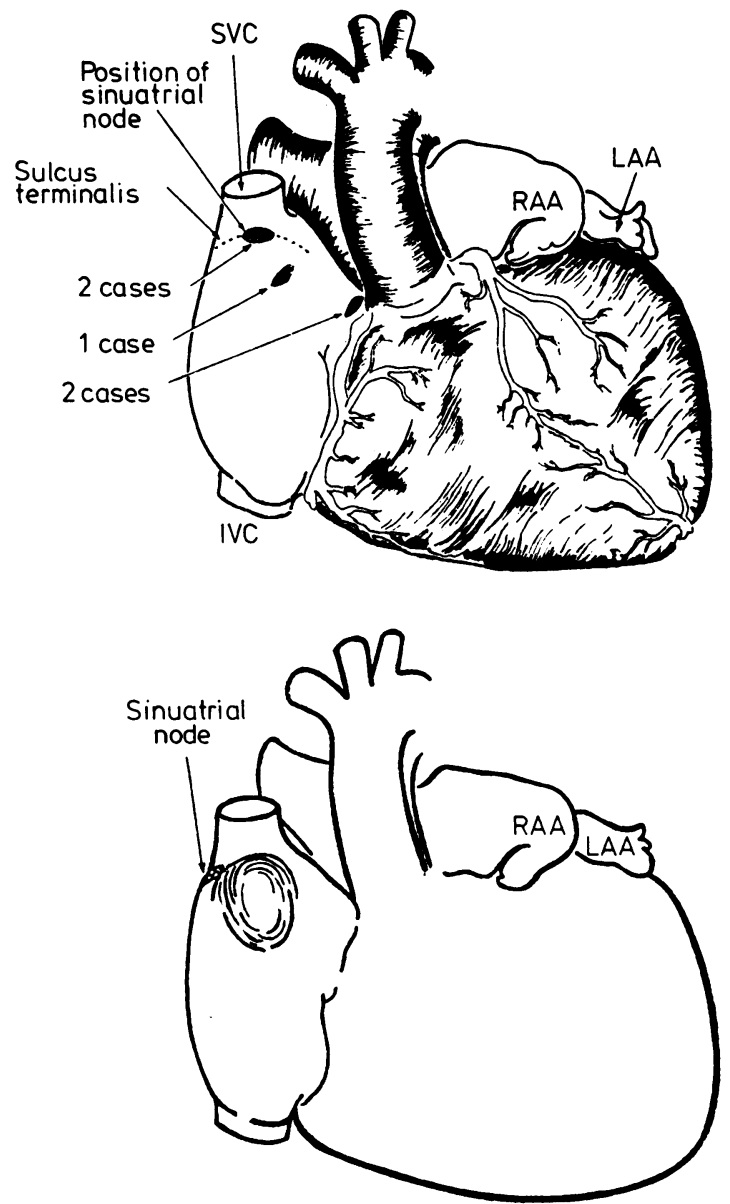

Fig. 3 Diagrams to show the positions of the sinus nodes in left-sided juxtaposition of the atrial appendages. The upper diagram shows the nodes in 5 cases of complete juxtaposition while the lower diagram shows the node in partial juxtaposition. In the latter case the node is in a more lateral position behind the 'bud' of the right atrial appendage. IVC, inferior vena cava; $L A A$, left atrial appendage; $R A A$, right atrial appendage; $S V C$, superior vena cava.

nodal artery was large and penetrated the node centrally after crossing the front of the right atrium.

\section{Discussion}

The sinuatrial nodes in the abnormal hearts did not differ histologically from the normal (Anderson et $a l .$, 1979). Their position did show more variation. In the normal, the node usually occupies a lateral position in the sulcus terminalis. In the hearts with juxtaposition, the node was more anterior, usually still being found in the sulcus terminalis but being 
located in an unusually low position in 2 cases. In the latter hearts the node was found on the dip of the anterior atrial wall towards the atrioventricular sulcus. The nodal artery in these cases was an anterior atrial branch of the artery which also supplied the roof of the left atrium. Retrospective study of the electrocardiogram showed that these 2 cases had a high $\mathrm{P}$ wave vector of $+90^{\circ}$ while the other cases were well within normal limits. The sixth case, with partial juxtaposition, showed a more normal position of the node behind the bud of the right atrial appendage on the right, being laterally located within the sulcus terminalis.

Contrary to Rosenquist et al. (1974), who commented that the crista terminalis was absent in their cases of partial juxtaposition, being invaginated into the juxtaposed right atrial appendage, the crista in all our cases was observed in its usual course and gave rise to pectinate muscles on the anterior atrial wall. As in the normal, its position was marked externally by the sulcus terminalis and consequently continues to provide a landmark to nodal position. As indicated, however, in 2 cases the node was inferior to the crista terminalis. None the less, in view of the consistent anterior location of the sinus node in complete juxtaposition of the atrial appendages together with the fact that the arterial supply is from an anterior artery, it is desirable to avoid this area in surgery, particularly in Fontan's procedure. The 2 inferior nodes appear to be located in a relatively safe area.

Although it is now possible to diagnose juxtaposition by cardiac catheterisation and angiography (Ellis and Jameson, 1963; Hunter et al., 1973; Deutsch et al., 1974) only one of our cases was diagnosed as such before operation. All our cases with left-sided juxtaposition were associated with severe ventricular and infundibulo-truncal malformations (Table) (Melhuish and Van Praagh, 1968; Anderson et al., 1976). Early diagnosis should draw the surgeon's attention to these anomalies, particularly the high probability of either presence of tricuspid atresia or hypoplasia of the right ventricle.

\section{References}

Allwork, S. P., Urban, A. E., and Anderson, R. H. (1977). Left juxtaposition of the auricles with l-position of the aorta. Report of 6 cases. British Heart fournal, 39, 299-308.
Anderson, R. H., Smith, A., and Wilkinson, I. L. (1976). Right juxtaposition of the auricular appendages. European fournal of Cardiology, 4, 495-503.

Anderson, K. R., Ho, S. Y., and Anderson, R. H. (1979). Location and vascular supply of sinus node in human heart. British Heart fournal, 41, 28-32.

Challice, C. E. (1966). Studies on the microstructure of the heart. I. The sino-atrial node and the sino-atrial ring bundle. Fournal of the Royal Microscopical Society, 85, 1-21.

Davies, F. (1942). The conducting system of the vertebrate heart. British Heart fournal, 4, 66-76.

Deutsch, V., Shem-Tov, A., Yahini, J. H., and Neufeld, H. N. (1974). Juxtaposition of atrial appendages: angiographic observations. American fournal of Cardiology, 34, 240-244.

Dixon, A. St. J. (1954). Juxtaposition of the atrial appendages: two cases of an unusual congenital cardiac deformity. British Heart fournal, 16, 153-164.

Ellis, K., and Jameson, A. G. (1963). Congenital levoposition of the right atrial appendage. American fournal of Roentgenology, Radium Therapy and Nuclear Medicine, 89, 984-988.

Fontan, F.. and Baudet, E. (1971). Surgical repair of tricuspid atresia. Thorax, 26, 240-248.

Hudson, R. E. B. (1960). The human pacemaker and its pathology. British Heart fournal, 22, 153-167.

Hunter, A. S., Hunderson, C. B., Urquhart, W., and Farmer, M. B. (1973). Left sided juxtaposition of the atrial appendages. Report of 4 cases diagnosed by cardiac catheterisation and angiocardiography. British Heart fournal, 35, 11841189.

James, T. N. (1970). Fetal and postnatal development. American fournal of Cardiology, 25, 213-226.

James, T. N., Sherf, L., Fine, G., and Morales, A. R. (1966). Comparative ultrastructure of the sinus node in man and dog. Circulation, 34, 139-163.

Keith, A., and Flack, M. (1907). The form and nature of the muscular connections between the primary divisions of the vertebrate heart. Fournal of Anatomy and Physiology, 4, 172-189.

Lev, M. (1968). The conduction system. In Pathology of the Heart and Blood Vesseis, 3rd ed., pp. 180-220. Ed. by S. E. Gould. Thomas, Springfield, Illinois.

Melhuish, B. P. P., and Van Praagh, R. (1968). Juxtaposition of the atrial appendages. A sign of severe cyanotic congenital heart disease. British Heart fournal, 30, 269-284.

Rosenquist, G. C., Stark, J., and Taylor, J. F. N. (1974). Anatomical relationships in transposition of the great arteries. Annals of Thoracic Surgery, 18, 456-461.

Truex, R. C., Smythe, M. Q., and Taylor, M. J. (1967). Reconstruction of the human sinuatrial node. Anatomical Record, 159, 371-378.

Requests for reprints to Dr Robert $\mathrm{H}$. Anderson, Cardiothoracic Institute, Brompton Hospital, Fulham Road, London SW3 6HP. 